\title{
DNI STUDIUM MARIOLOGICZNEGO NA JASNEJ GORZE
}

W dniach od 9 do 13 sierpnia br. odbyły się na Jasnej Górze w Częstochowie Dni Studium Mariologiczenego, poprzedzające ogólnopolski Kongres Maryjny, który miał miejsce 14 i 15 sierpnia br. Studium Mariologiczne zgromadziło niemal wszystkich mariologów polskich zarówno duchowych jak i świeckich i poświęcone było wszechstronnemu omówieniu tematu „Królewskości Matki Bożej“.

Obrady rozpoczęto 9. VIII., wieczorem o godz. 19 odprawieniem wspólnych modlitw w cudownej kaplicy Matki Bożej Częstochowskiej. Na powyższe modlitwy złożyły się: Msza św. celebrowana przez JE. Ks. Bpa Dra Z. Golińskiego, Ordynariusza diec. częstochowskiej, nabożeństwo do M. B., odprawione przez JE. Ks. Bpa Dra A. P a w 10 wskiego z Włocławka, oraz konferencja ascetyczna JE. Ks. Bpa Dra K. Kowalskiego z Pelplina.

Po nabożeństwie uczestnicy zjazdu naukowego przeszli do kaplicy różańcowej, gdzie wszystkich w serdecznych słowach przywitał O. B. Przybylski OP., Przewodniczący Jasnogórskiego Studium Maryjnego, oraz powołał Prezydium Kongresu. Z kolei oddał glos O. Prof. A. Krupie OFM., z KUL'u który wygłosił swój inauguracyjny referat pt. „Magisterium Kościoła o królewskości N. Marii Panny". Czcigodny referent zaznaczył w swoim adczycie że pojęcie godności i władzy królewskiej N. M. P., nie ma nic wspólnego z godnością królowej panującej na ziemi, lecz czerpie swoje podstawy z boskiego macierzyństwa M. B., oraz z Jej udziału w zbawczym dziele Jezusa Chrystusa. Często swoje wywody popieral Czcig. referent wypowiedziami ostatnich papieży, szczególnie Piusa XII, zawartymi głównie w jego encyklice „Ad coeli Reginam".

Przez następne trzy dni odbywały się do południa zebrania plenarne, na których wygłaszano ogólne, ramowe referaty, zaś po południu aby dogłębnie i wszechstronnie omówić zaplanowany temat królewskości Marii, uczestnicy naukowego zjazdu podzielili się na trzy sekcje: 1) sekcję teologii pozytywno-spekulatywnej, 2) sekcję kultowo-historyczną oraz 3) sekcje duszpasterską. Podany na zebraniach sekcyjnych w referatach materiał, poddawano jeszcze raz szczegółowej analizie podczas żywych i konstruktywnych dyskusji. 
W pierwszym dniu obrad na zebraniu plenarnym wygłoszono następujące referaty: O. Edward $\mathrm{H}$ ar a ty m TJ., „Króleuskość NMP. $w$ Piśmie św.", Ks. Prof. dr Eug. Fl ork ow ski z Krakowa „Królewskość NMP. w patrystyce $i$ historii teologii" oraz JE. Ks Bp Dr Andrzej Wronka z Wrocławia „Królewskość NMP. w liturgii". po południu na sekcji pozytywno-spekulatywnej wygłoszono referaty: O. Romuald Kostecki OP., z Krakowa „Macierzyństwo $i$ Królewskość NMP.“ oraz O. Aleksander Glink a OFM., także z Krakowa, "Udziat NMP. $w$ odkupieniu jako podstawa dla jej Królewskości“. Żywa dyskusja, jaka wywiązała się szczególnie wokół tematu macierzyństwa NMP. i jej królewskiej godności była wyrazem wielkiego zainteresowania się mariologów, szczególnie tym tematem.

W drugim dniu obrad na posiedzeniu plenarnym przemawiali: O. B. Przy by $1 \mathrm{ski}$ OP. na temat „Istota $i$ zasiẹg Królewskości NM.P., oraz Ks. Rektor Wł. Miziołek z Warszawy, który wygłosił referat pt. „Podstawy i zarys kultu Maryi Królowej Polski“. P. Zofia Kossak z Warszawy mówiła o „Dziejach Kultu Matki Bożej w Polsce”. Po południu sekcja pozytywno-spekulatywna poświęciła prawie $\mathrm{w}$ całości swój czas na referat Ks. Prof. dra Ignacego Różyckiego z Krakowa na temat: „Królewskość NMP. w całokształcie Jej przywilejów". Czcigodny Referent $w$ jasnych i rzeczowych wywodach wskazał na zasadnicze przywileje Matki Bożej, które stanowią wystarczającą motywację przy nadawaniu Jej tytułu Królowej. Referat Ks. Prof. R óż y ckiego został przez zebranych przyjęty z wielkim uznaniem.

Referaty trzeciego dnia ukazały aspekty królewskości Matki Bożej w literaturze i sztuce polskiej w doskonałym ujęciu Mgr Stefana Sawickiego z KUL'u pt. „Matka Boża $w$ literaturze polskiej" oraz Ks. Prof. Dra Wł. S mole n i a z Tarnowa „Maria - Królowa Polski w sztuce“. Ks. Prof. Dr Fr. B r a ch a CMI., z Krakowa mówił na temat „Perspektywy rozwoju pracy mariologów polskich", podkreślając konieczność opracowania summy mariologicznej O. Justyna Mi echowity największego mariologa polskiego.

Po południu na sekcji pozytywno-spekulatywnej wygłoszono jeszcze trzy referaty, które były już podsumowaniem dotychczasowych rozważań na temat Królewskości Marii. Ks. Prof. Dr Wł. K a s p r z a k z Krakowa mówił na temat „Królewskość NMP., w encyklice „Ad coeli Reginam“, Ks. Prof. Dr Andrzej B o b e r TJ., z Krakowa „Królewskość NMP. u późniejszych Ojców Kościoła“, oraz Ks. Prof. Lucian Strada podzielił się z zebranymi uwagami na temat: „Maria Królowa - Wspomożycielka wiernych".

Równolegle do sekcji pozytywno-spekulatywnej toczyły się obra:dy w dwóch jeszcze innych sekcjach: historyczno-kultowej i w sekcji teologii duszpasterskiej. Sekcja historyczno-kultowa dała referaty pracownilków KUL'u. Mgr Czesław De ptu 1 a mówił na temat: ,Z zagadnién 
historii kultu maryjnego“, Dr Ewa J a b lońs k a, zreferowala „Specyfike polskiego kultu maryjnego na podstawie wybranych pamiętników 19-wiecznych" araz Doc. Jerzy Kloczowski przedstawił "Metody badań socjo-historycznych kultu". Poza tym wygloszono jeszcze na tej samej sekcji referaty: Ks. Dr W. Malej, „Reginae Poloniae maiestas in iconibus observata", O. R. S wi ętochowski OP., „Źródla archiwane dotyczqce dziejów Różańca w Polsce", oraz S. Krysta Niepokalańka, „O szerzeniu kultu Najśw. Panny w epoce Piastow". Obrady sekcji kultowej toczyły się $\mathrm{w}$ małym gronie, ale żywe dyskusje i liczne rezolucje $\mathrm{z}$ bogatym planem pracy na przyszły rok świadczyły o poważnym wysiłku tejże sekcji. Postanowiono na przyszłość między innymi także przeprowadzić inwentaryzacje materiałów maryjnych znajdujących się $\mathrm{w}$ różnych archiwach i bibliotekach, zebrać dokumenty do dziejów kultu maryjnego zwłaszcza z różnych sanktuariów maryjnych słynących cudami, oraz prowadzić na bieżąco dokumentację życia maryjnego po parafiach.

$\mathrm{Z}$ obrad sekcji teologil duszpasterskiej, najliczniej reprezentowanej zwrócić należy uwagę na takie referaty jak O. B. Przybylskiego OP., „Mariologia w duszpasterstwie“, Ks. Prob. Dra St. Wój towi cza, z Bochni „Królewskość NMP. przedmiotem duszpasterstwa", O. Sykstusa S z a frán ca Paulina,„Przejawy kultu Królewskości NMP.“ i inne.

Zakończenie abrad Dni Studium Mariologicznego odbyło się $\mathrm{W}$ sobotę 13 sierpnia, wygłoszeniem ostatniego referatu przez JE. Ks. Bpa Antoniego P a w łow skiego pt. „Duchowość maryjna“. Dostojny Referent podkreślił mocno w swoim przemówieniu, że N. Marria Panna to nie abstrakcja, ale ideał osobowy zobowiązujący do naśladowaniá, oraz pełnego zalangażowania swoich sił zarówno duchowych jak i fizycznych. $\mathrm{Na}$ zakończenie odczytano tekst telegramu wysłanego do Ojca Swiętego J a n a XXIII, oraz JEm. Ks. Kardynal Prymas Stefan W y szyński zachęcił zebrnych do dalszych owocnych wysiłków i prac na niwwie mariologii polskiej. Prace te muszą być syntezą solidnych naukowych badań, pozbawionych zarozumiałości i pychy $z$ pokorną i nadprzyrodzoną postawa każdego badacza-teologa. Tematem następnych dni mariologicznych ma być problem duchowego macierzyństwa Najśw Maril Panny.

Kraków

Ks. STANISEAW GRZYBEK 